\title{
Correction to: Leucine-rich glioma- inactivated protein 1 antibody-mediated autoimmune encephalitis in a 4-year-old girl: a case report
}

Junxia Luo ${ }^{1 \dagger}$, Jianguo Shi ${ }^{2+}$, Yehong Chen ${ }^{1}$, Wandong Hu${ }^{1}$, Yujie Guo ${ }^{1}$, Guangshun Hou ${ }^{1}$ and Zaifen Gao ${ }^{1 *}$

\section{Correction to: Acta Epileptologica 3, 4 (2021) \\ https://doi.org/10.1186/s42494-021-00039-z}

After publication of this article [1], it is reported the below corrections need to be made with it.

1. The following sentence need to be added to the end of 'Background' section:

"This study was approved by the Institutional Ethics Committee of Qilu Children's Hospital of Shandong University and informed consent has been obtained from the guardian of patient prior to analysis."

2. 'Ethics approval and consent to participate' section in the back matter should be revised to:

"This study was approved by the Institutional Ethics Committee of Qilu Children's Hospital of Shandong University and informed consent has been obtained from the guardian of patient prior to analysis."

3. 'Consent for publication' section in the back matter should be revised to:
"All authors and the guardian of patient agreed for the publication of this study."

The original article has been updated.

\section{Author details \\ ${ }^{1}$ Neurology Department, Qilu Children's Hospital of Shandong University, Jinan, China. 'Functional Neurosurgery Department, Qilu Children's Hospital of Shandong University, Jinan, China.}

Published online: 10 June 2021

Reference

1. Luo J, Shi J, Chen Y, et al. Leucine-rich glioma-inactivated protein 1 antibody-mediated autoimmune encephalitis in a 4-year-old girl: a case report. Acta Epileptologica. 2021;3:4. https://doi.org/10.1186/s42494-02100039-z.

* Correspondence: gaozaifen@163.com

†Junxia Luo and Jianguo Shi contributed equally to this work.

${ }^{1}$ Neurology Department, Qilu Children's Hospital of Shandong University,

Jinan, China

Full list of author information is available at the end of the article

(c) The Author(s). 2021 Open Access This article is licensed under a Creative Commons Attribution 4.0 International License, which permits use, sharing, adaptation, distribution and reproduction in any medium or format, as long as you give appropriate credit to the original author(s) and the source, provide a link to the Creative Commons licence, and indicate if changes were made. The images or other third party material in this article are included in the article's Creative Commons licence, unless indicated otherwise in a credit line to the material. If material is not included in the article's Creative Commons licence and your intended use is not permitted by statutory regulation or exceeds the permitted use, you will need to obtain permission directly from the copyright holder. To view a copy of this licence, visit http://creativecommons.org/licenses/by/4.0/. 